\title{
A Crystal Clear Vision: Celebrating the Multi-Faceted Legacy of Kathleen Lonsdale
}

\section{Lynne Robinson}

\section{Pioneers in Diversity}

This profile of Kathleen Lonsdale marks the first in an ongoing series of JOM articles highlighting individual contributions to a more diverse minerals, metals, and materials science and engineering community. The series is an ongoing project of the TMS Women in Materials Science and Engineering Committee as an effort to raise awareness of diversity topics within the field, while also celebrating the accomplishments of those who have made inroads on these issues.

"I believe in good. Not just as a hypothesis. It really is a leap of faith and absolutely fundamental to all my way of life."

Up until that statement during a

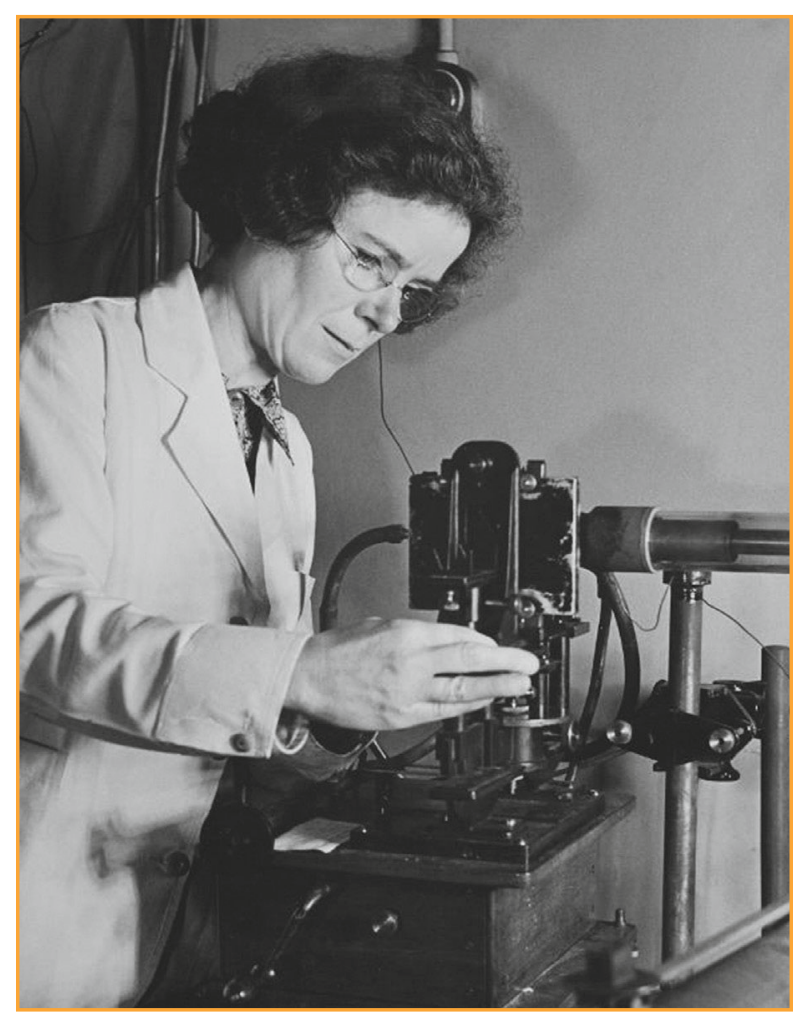

Kathleen Lonsdale helped establish the theoretical foundation for the field of crystallography. (Photo: University College London Library Services (02010)
November 1967 BBC radio interview, Kathleen Yardley Lonsdale's tone had been relatively light, as she patiently defined crystallography for the masses and explained how she managed to raise three children while pursuing a demanding career. ("[I married] a husband who helped me in every way," she said. "Particularly when things got difficult, he encouraged me to go on with my work. He also does the cooking and is very good on bread and cakes.") When the conversation turned to her perspectives on social responsibility, an edge of urgency entered her voice, indicating how close the topic was to her heart.

"A scientist should take interest in national and international affairs, not as a politician, but in making sure that facts are properly known and trying to ensure that science is used for good and not for evil purposes," she said. "International understanding between scientists can lead to international understanding in other ways. And, this is not only the role of the scientist, but also the role of educated people of all kinds."

While science was Kathleen Lonsdale's passion, it was her dedication to "doing good" in the world that defined her life. A protégé of William Henry Bragg, Lonsdale was one of the early pioneers in establishing the science of x-ray crystallography, while also leveraging her considerable talent and determination to open doors for other women to pursue scientific careers. Along the way, she served time for refusing civilian service in World War II, worked tirelessly for prison reform, and was an internationally recognized activist for world peace.

"She had a kaleidoscope of interests. They were all very important and all very much part of her," said Maureen Julian, who studied under Lonsdale as a research fellow at University College London.

"As a scientist, she believed she had an obligation to not only make contributions to her field, but to areas completely outside of her field." 


\section{"A Wonderful Sense of Mathematics"}

Lonsdale credited being "one of a large family" as an early influence on her character, having been born the youngest of ten children in 1903 in Ireland. Her parents, Jessie and Harry Yardley, a postmaster for the local British garrison, separated when she was five, and her mother moved herself and her children to Seven Kings, England, for a fresh start. Unfortunately, Seven Kings would soon find itself in the shadow of the zeppelin raids on England during World War I. "Living through that experience was what caused her great hatred of war," said Julian.

A high school education in Great Britain at the time was usually only available to families of means, compelling Lonsdale's older siblings to leave school by their early teens to enter the workforce. Lonsdale, however, was able to secure a scholarship to the County High School for Girls in Ilford. Recognizing that she was exceptionally gifted in science, her teachers arranged for her to take chemistry, physics, and mathematics at the local boys' school since the girls' school did not offer those classes. At the age of 16, she was accepted to the Bedford College for Women, graduating in 1922 with the highest grades earned in a decade. "Her school mistresses tried to persuade her to stay on an extra year in high school, believing that she could then successfully apply to Oxford or Cambridge," said Julian. "She was very anxious to get on with her advanced studies, though, and

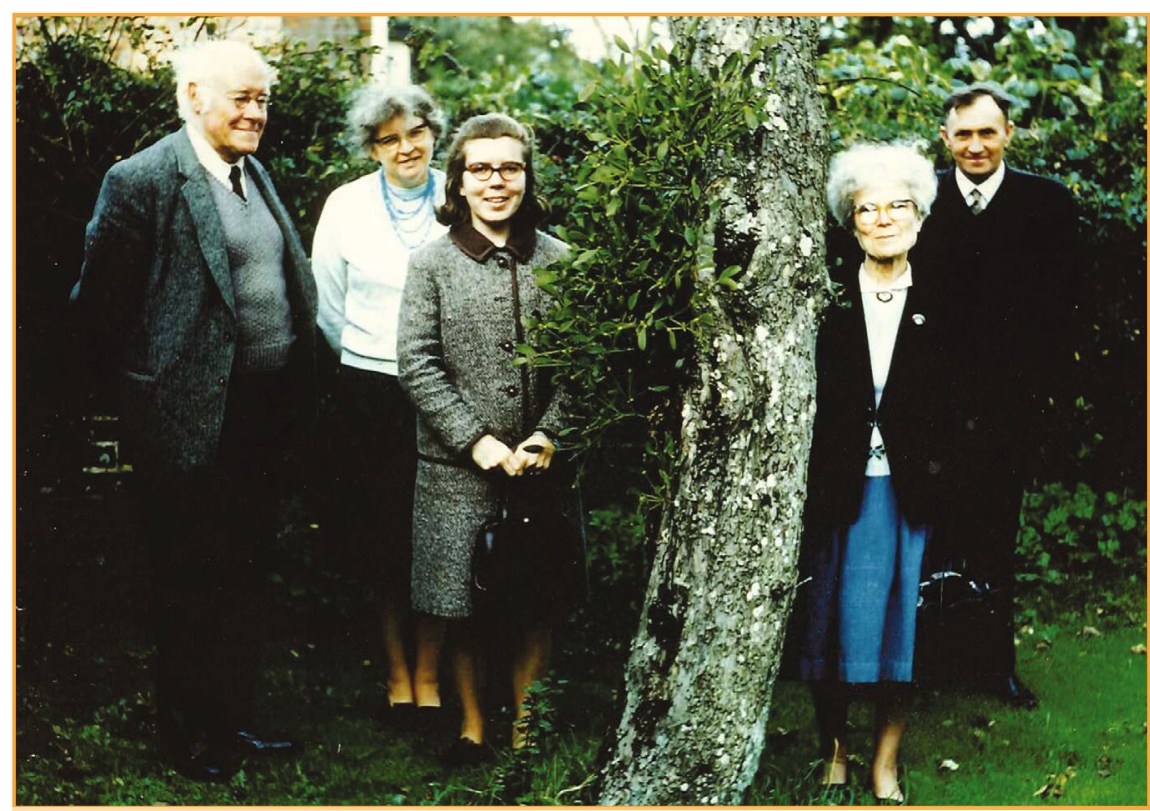

(From right): Kathleen Lonsdale, Maureen Julian, and Thomas Lonsdale at a Quaker meeting with two friends in 1968. "She was the greatest influence on my own life, personally, professionally, and morally," said Julian. (Photo courtesy of Maureen Julian)

once she made up her mind, nothing would stop her."

As it turned out, attending Bedford did much more than accelerate Lonsdale's college career. It was there that Lonsdale first met William Henry Bragg, who was one of her examiners for the oral finals required for her degree. Bragg and his son, William Lawrence, had essentially founded the science of crystallography, sharing a 1915 Nobel Prize in physics for advancing the analysis of crystal structure using x-ray diffraction. Deeply impressed with Lonsdale's academic accomplishments, Bragg offered her a position in his laboratory to study the crystal structure of organic compounds. She started as soon as she graduated, working with Bragg's team

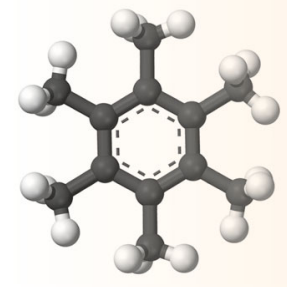

"Small girls don't learn to use tools like small boys, and I think they should. They can use chisels and screwdrivers as well as boys can, if they can use scissors and a needle. This makes it difficult to begin experimental work."

-Kathleen Lonsdale, in 1967, on why more girls don't pursue scientific careers. 
giving up scientific research to start raising a family, but Thomas Lonsdale convinced her otherwise, saying he "had not married to get a free housekeeper." Said Julian, "They had a very happy marriage. Tom supported Kathleen in every way and was so very proud of her."

\section{Making the Most of Every Situation}

While Thomas Lonsdale worked by day and conducted experiments at night in the kitchen to complete his doctoral dissertation, Kathleen Lonsdale continued her research at the University of Leeds with crystals of hexamethylbenzene given to her for analysis by the English chemist, C.K. Ingold. The crystals were not easy to work with, but their unique characteristics gave Lonsdale the insight she needed to confirm the structure of the benzene ring - $\mathrm{a}$ riddle that had eluded scientists, including William Henry Bragg, for years. In fact, her experimental evidence proving that the ring was hexagonal and flat (as shown in the masthead and sidebars of this article) directly contradicted Bragg's own theories that the ring was puckered. "Bragg was very supportive of her, but I also think she was quietly pleased that her result had disproved his theory," said Julian. Lonsdale's accomplishment still stands as a basis for organic chemistry analysis.

The Lonsdales moved back to London in 1930, this time with the first of their three children in tow, when Thomas accepted a new position at the Testing Station of the Experimental Roads Department in the Ministry of Transport. Kathleen Lonsdale worked out of their home, laboriously calculating the structure factor tables that she had started in graduate school and typing them out on a used typewriter with an extra-long platen that could fit the formulas. She published these in 1936 as Simplified Structure Factor and Electron Density Formulae for the 230 Space-Groups of Mathematical Crystallography. She received her

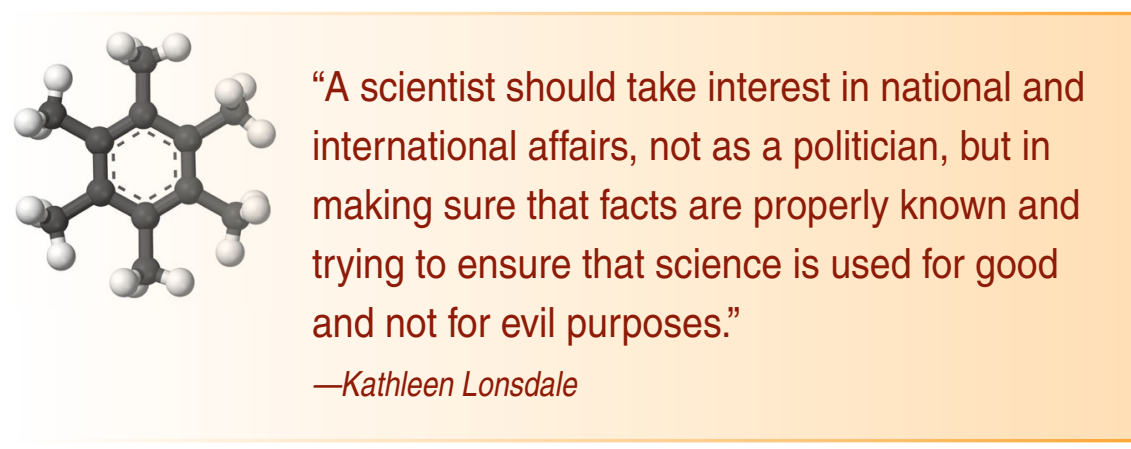

doctorate of science for her study of ethane derivatives contained in that volume. It was also the nucleus of what would become one of her most important contributions - the creation of the International Tables for X-ray Crystallography. Lonsdale would later go on to serve as the editorin-chief of the first three volumes of the tables, which to this day are considered essential references in crystallography.

In the meantime, William Henry Bragg was able to secure funds that enabled Lonsdale to get support at home so that she could return to the Royal Institution to work with his research group. She was initially disappointed to discover that there was no $\mathrm{x}$-ray equipment in her new laboratory. A large and rather old electromagnet offered possibilities, so she conducted experiments with that while the $\mathrm{x}$-ray equipment was on order. Her "make do" efforts resulted in her proving the difference between sigma and pi electronic orbitals, which established the existence of molecular orbitals. "She loved to tell that story as an example of taking advantage of opportunities as they come, even if they are not quite what you expect," recalled Julian.

Lonsdale worked with Bragg until his death in 1942. In 1943, she experienced what Thomas Lonsdale described as "the most transforming thing that ever happened to her."

She went to jail.

\section{A Scientist and Activist}

A devout Quaker since 1935, Kathleen Lonsdale saw no good in war, although she did not fault soldiers for carrying out their orders, noted Julian. As World War II broke out, she did her part to help her neighbors and community, even offering her home to shelter refugees. The line she would not cross was to become part of the formal war organization by participating in the civil defense service. Lonsdale made a point of detailing her objections to civil defense registration in writing - and then refused to pay the fine of two pounds. Her principles landed her in Holloway Prison for a month. Julian related that when the prison warden observed to Lonsdale that it was not uncommon to ignore registering for civil defense service and that most people did not go to prison for doing so, Lonsdale replied, "They probably didn't write and tell them why."

Julian said that Lonsdale's experiences in prison started her on the path to becoming a public figure. "Before that, she had never spoken publicly. She really didn't have the confidence, like many women at the time," she commented. "In prison, she talked with the inmates and was impressed by many of their stories. She felt a need to speak out on their behalf about conditions and the warden took many of her suggestions. From there, she made a name for herself internationally as both a scientist and an activist." Lonsdale subsequently served on a number of prison boards in Great Britain and whenever she traveled abroad for a scientific visit, she usually arranged a tour of a local women's prison as well. "She would ask very penetrating questions," said Julian. "A warden in Russia once asked her 'how such a nice lady knows so much 
about prison."”

Lonsdale's commitment to world peace also took a very public turn in the 1950s with the advent of nuclear testing by Russia, the United States, and Great Britain. In 1956, she took a sabbatical from her scientific work to write her book, Is Peace Possible? "I feel a sense of corporate guilt and responsibility that scientific knowledge should have been so misused," she wrote in the forward. She lectured extensively on the topic as well, eventually serving as vice president of president of the Women's International League for Peace and Freedom.

\section{"A Good Example of Many Things"}

After World War II, Lonsdale left the Royal Institution for University College London, becoming its first female tenured professor in 1949. Maureen Julian worked with her there in the 1960s, focusing primarily on the work that Lonsdale was leading in solid state reactions. Lonsdale had also devoted a portion of her laboratory to the study of natural and synthetic diamonds, as well as minerals at high temperatures and pressures. To celebrate her contributions in this area, a rare form of meteoric diamond was named lonsdaleite in her honor in 1966. Lonsdale accepted the recognition with characteristic humor: "It makes me feel both proud and rather humble that it shall be called lonsdaleite. Certainly the name seems appropriate since the mineral only occurs in very small quantities (referring to her tiny stature. Lonsdale barely weighed 100 pounds.) and is generally rather mixed up!" the Atomic Scientists' Association and

\section{Breaking Barriers}

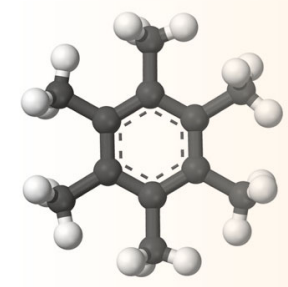

As a pioneering female scientist, Kathleen Lonsdale achieved a number of notable "firsts," including:

1945 -First woman, along with Marjory Stephenson, to be elected as a Fellow to the Royal Society in London.

1949-First female tenured professor at the University College London.

1966-First female president of the International Union of Crystallography.

1967-First female president of the British Association for the Advancement of Science.
A third area of study in Lonsdale's laboratory was the analysis of body stones. Julian noted that she particularly enjoyed showing off an x-ray diffraction image of Napolean III's bladder stone. "She saw tremendous mystery and wonder in nature, which I believe is why she had such diverse interests," said Julian. "She was always taking up new problems and if anyone posed a really good question, she would try to answer it."

"I don't think she singled out a particular accomplishment to be proud of, although there were many," Julian continued. "I think she was most proud of her total life and that she was able to influence so many people on different levels."

One of those people included Queen Elizabeth II, whom Lonsdale first met when she was named a Dame Commander of the Order of the British Empire in 1956. She approached royalty in the same down-to-earth manner that she applied to everyone, even making her own hat for one of

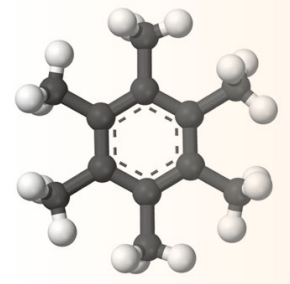

"I was of a skeptical turn of mind and found I had to reject a good deal of what I had been taught and think things out very thoroughly for myself, which took a great many years in discussions with colleagues and later with my husband." her audiences with the queen. ("The straw cost me nine pence and I got little bits of lace and ribbon from my usual store. I think it was a great success.")

"I think what I admired most about her was her honesty. She was so straightforward about everything," said Julian. "And, she treated everyone with dignity, from women in prison to the queen."

Lonsdale died of cancer in 1971, working into her last days on a book on body stones. (Julian believes that she sneaked out of the hospital at least once to gather references.) "She lived such a rich and joyful life and had great fun in her work. She would say that she skipped to the lab every day," said Julian. "I think what we can all learn from her is to do something that you thoroughly enjoy, but also develop yourself in many different ways and find balance among those different interests. She was a good example of many things - a scientist, a mother, and a peace activist among them. And, she made the world a better place as a result."

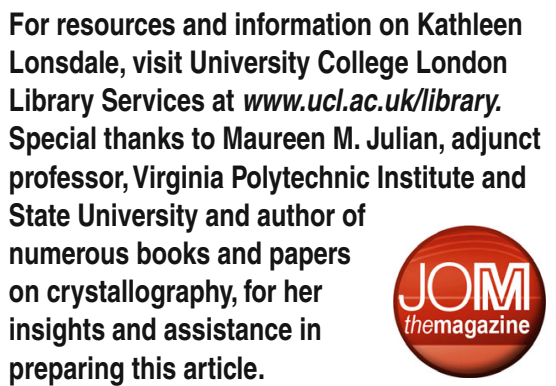
Lonsdale, visit University College London Library Services at www.ucl.ac.uk/library. Special thanks to Maureen M. Julian, adjunct professor, Virginia Polytechnic Institute and State University and author of on crystallography, for her preparing this article. 